\title{
SNPs within Exon VIII of DGAT1 Gene in Gaolao Cattle
}

\author{
S. N. Pantawane ${ }^{1}$, D. S. Kale ${ }^{1 *}$, P. G. Koringa ${ }^{2}$ and D. V. Patil ${ }^{1}$ \\ ${ }^{1}$ Department of Animal Genetics and Breeding, Nagpur Veterinary College, Maharashtra \\ Animal and Fishery Sciences University (MAFSU), Nagpur, India \\ ${ }^{2}$ Department of Animal Biotechnology, College of Veterinary Science and A.H., Anand \\ Agricultural University, Anand, India \\ *Corresponding author
}

Keywords

DGAT1, Gaolao Cattle, HRM, PCRRFLP, Sequencing, SNP

\section{Article Info}

Accepted:

12 December 2020

Available Online:

10 January 2021
DGAT1 gene is major candidate gene and K232A polymorphism revealed pronounced influence on fat percentage in cattle milk. It was planned to reveal polymorphisms within regions of DGAT1 gene in Gaolao cattle using PCR-RFLP and DNA Sequencing and to find association between polymorphisms and milk production traits. DNA was extracted from purebred Gaolao cattle. DGAT1G1-CfrI locus in Exon-VIII region exhibited monomorphic pattern; however DGAT1G2-BglI locus was polymorphic with frequency for the $\mathrm{K}$ alleles as 0.9875 and for allele $\mathrm{A}$ as 0.0125 in Gaolao population. The animals exhibiting PCR-RFLP as AA (K) \& GC (A) genotype were sequenced which revealed one SNP T-G at $231^{\text {st }}$ position. DNA sequencing of HRM analysed DGAT1G3-212 bp amplicons revealed 03 polymorphic sites as computational SNPs at $52^{\text {nd }}$ position as SNP $\mathrm{G}-\mathrm{A}$, at $51^{\text {st }}$ position as SNP G -A and at $67^{\text {th }}$ position as SNP A-G. DGAT1G4 amplified sequence revealed SNP, C-A at $23^{\text {rd }}$ position. In various studies, the allele $(\mathrm{K})$ encoding the lysine variant has proved to be associated with regard to the milk fat synthesis, and which can be a useful marker for milk fat traits in selection and breeding.

\section{Introduction}

The genetically uniform systems are vulnerable to extreme and adverse weather conditions, emerging diseases and pathogens. Livestock biodiversity is crucial for sustaining long term sustainable productivity (Frison et al., 2010). Declining Gaolao cattle exhibits relatively low milk yield and better adaptability, disease-resistance and feed efficiency. To stop declining trend in breeding population of Gaolao Cattle; conservation and genetic improvement is need of hour.The average milk yield per lactation is $604 \mathrm{Kg}$ with average $4.32 \%$ Fat (Kargirwar, 2004). The breeding tract of Gaolao cattle is spread in Wardha and Nagpur districts of Maharashtra, Balaghat and Chindwara districts of Madhya Pradesh and Rajnandgaon district of Chhattisgarh.

Diacylglycerol O-Acyltransferase 1 (DGAT1) gene is a candidate gene (Kennedy et al., 1957; Weiss et al., 1956) and is a lipogenic 
enzyme which plays key role in the synthesis of triacylglycerols. It is located on bovine chromosome 14 which is of size $14,117 \mathrm{bp}$ consisting of 17 exons. The substitution named ApA to $\mathrm{GpC}$ dinucleotide is located in exon VIII of bovine DGAT1 gene which replaces lysine $(\mathrm{K})$ by alanine $(\mathrm{A})$ in encoded protein (K232A polymorphism) has pronounced influence on milk yield and composition, especially on fat percentage in milk (Grisart et al., 2002; Winter et al., 2002; Kaupe et al., 2004; Lacorte et al., 2006; Fangyu et al., 2020). The DGAT1 lysine variant $(\mathrm{K})$ is associated with increasing fat yield, fat and protein percentage and the alanine variant (A) is associated with increasing protein and milk yield (Bennewitz et al., 2004; Patel et al., 2009; Berry et al., 2010).

A range of molecular markers, which reflect breed evolution, recent demographics and economic potential, needs to be applied in combination to provide optimal data for livestock management and conservation (Bruford et al., 2003). The SNPs are genetically stable selection markers and abundant in genome used for genotyping and amenable to high-throughput automated analysis (Heaton et al., 2002). Current advances in molecular genetic techniques has provided opportunity to reveal significant candidate gene variants in Gaolao cattle related with milking traits. In view of this current study was planned to study the polymorphisms within regions of DGAT1 gene in Gaolao cattle to detect SNPs within DGAT1 gene in Gaolao Cattle.

\section{Materials and Methods}

\section{Experimental Animals and Data}

The present study consisted of purebred Gaolao cows from Farmer's herds \& Breeding Farm. The information sheet was generated to record individual cow records as milk traits related phenotypic data. Milk components like Fat \%, Protein \%, SNF \% \& Lactose $\%$ were estimated using milk analyzer.

\section{Blood collection \& DNA extraction}

Blood in the quantity of around $05 \mathrm{ml}$ was collected from jugular vein in a vacutainer tube containing EDTA from 40 experimental cows. DNA extraction procedure was carried out using Blood DNA Isolation Kit (HiPurA SPP, Himedia) as per the manufacturer's guidelines. The quality and quantity of the genomic DNA was assessed using agarose and Nanodrop before its use in PCR amplification.

\section{Primers and primer designing}

The primers reported by other researchers were used for screening Gaolao cattle population at DGAT1 locus and some primers for other regions (exon VIII and intron I) of DGAT1 were designed (www.primer3.com) based on the reference sequence (AJ318490) (Table 1).

\section{Polymerase Chain Reaction (PCR)}

PCR reaction of $25 \mu \mathrm{l}$ volume were carried out using 50ng of genomic DNA, $10 \mathrm{pM}$ concentration for the primers DGAT1G1, DGAT1G3 and DGAT1G4 and $1^{\mu} \mathrm{M}$ concentration for the primer DGAT1G2 (Forward and Reverse), 12.5ul of PCR 10X Go taq Master mix (Promega). The PCR thermal cycling conditions for DGATG1, DGAT1G3 and DGAT1G4 were set on thermal cycler (Himedia eco96) as below; initial denaturation for $94^{\circ} \mathrm{C}$ for 5 minutes, denaturation at $94^{\circ} \mathrm{C}$ for 30 seconds, annealing at $61.5^{\circ} \mathrm{C}$ for 30 seconds, extension at $72^{\circ} \mathrm{C}$ for 30 seconds ( 35 cycles) and final 
extension at $72^{\circ} \mathrm{C}$ for 10 minutes. However for DGAT1G2 thermal cycling conditions were as; initial denaturation for $94^{\circ} \mathrm{C}$ for 5 minutes, denaturation at $94^{\circ} \mathrm{C}$ for 30 seconds, annealing at $58.5^{\circ} \mathrm{C}$ for 30 seconds, extension at $72^{\circ} \mathrm{C}$ for 30 seconds (30 cycles) and final extension at $72^{\circ} \mathrm{C}$ for 10 minutes. Four regions 411 bp of exon VIII, 378 bp of exon VIII, 212 bp of intron 1 and 198 bp of exon VIII of DGAT1 gene were amplified using DGAT1G1， DGAT1G2， DGAT1G3 \& DGAT1G4 primers using $10 \mathrm{pM}, 1 \mu \mathrm{M}, 10 \mathrm{pM}$ and $10 \mathrm{pM}$ concentrations respectively. The PCR products of DGAT1 gene were resolved in $2.5 \%$ agarose gel electrophoresis at $50 \mathrm{~V}$ for 45 minutes. The PCR amplified products were visualised for compact and sharp amplification with desired product size under Gel Documentation System.

\section{PCR-RFLP}

The restriction enzymes were used for digestion of the amplified PCR products (Table 2) using specific concentration and quantity at recognition site which needs to be polymorphic for variation in the population. The RE/ CfrI treated PCR products were incubated for complete digestion at $37^{\circ} \mathrm{C}$ for 6 hours. The mixture of PCR Product and restriction enzyme/ $B g l \mathrm{I}$ was kept for RE digestion at $37^{\circ} \mathrm{C}$ for 3 hours.

\section{High resolution melting (HRM) analysis \& protocol}

HRM is a mutation scanning method (Wittwer et al., 2003) used for analysis of genetic variation as well as mutation. HRM is based on thermodynamic differences between DNA fragments. The amplicons of $212 \mathrm{bp}$ DGAT1 gene representing intron 1part of gene obtained using DGAT1G3 primer were selected for HRM analyses. The following were the components required to be processed for HRM analysis;

a. Genomic DNA (50ng/ $\mu \mathrm{l})$ - 40 samples

b. 212 bp PCR product obtained using DGAT1G3 primer

c. Real time PCR and HRM

The PCR products were first carefully optimized to get sharp and precise amplification before its HRM analysis. The same products were again set at optimized conditions for HRM analysis as bellow;

96 well plate was taken \& 40 wells were used, in each $20 \mu$ l Master mix was added

PCR was set at the following thermal cycling conditions; $95^{\circ} \mathrm{C}$ for 15 minutes, $94^{\circ} \mathrm{C}$ for 60 seconds, $61^{\circ} \mathrm{C}$ for 60 seconds, 40 cycles, $72^{\circ} \mathrm{C}$ for 60 seconds and $72^{\circ} \mathrm{C}$ for 10 minutes.

A melt curve graphs were generated based on slowly melting the DNA sample through a range of temperatures in the presence of a dsDNA-binding dye.

\section{Direct DNA sequencing \& Sequence analysis using Bioinformatics Tools}

Based on PCR-RFLP and HRM analysis results, PCR products amplified were selected for confirmation of mutation by sequencing. The obtained DNA sequences were edited and analyzed using various bioinformatics tools for detection of nucleotide substitutions.

\section{Statistical analysis}

Genotype and allele frequencies were estimated using POPGENE Version 1.31 (Yeh and Boyle, 1997). The obtained gene \& genotype frequencies were tested for deviation from Hardy-Weinberg equilibrium (HWE) by using a Chi-square test (Devlin and Risch, 1995; Nielsen et al., 1998). The relationship between the milk component and 
genotype was tested using one-way ANOVA. The mathematical equation was given by,

$Y i j=\mu+\tau i+\epsilon i j$,

Where,

$Y i j=$ the milk component of $i^{\text {th }}$ cow for the $j^{\text {th }}$ genotype

$\mu=$ the average milk component

$\tau i=$ average effect of the $j^{\text {th }}$ genotype

$\epsilon i \mathrm{j}=$ error effect, All the analysis was done by

SPSS Version 20 (IBM, USA).

\section{Results and Discussion}

\section{PCR-RFLP DGAT1G1-CfrI locus}

Restriction digestion analysis of 411 bp PCR product of the exon VIII region of DGAT1 gene with $C f r I$ enzyme exhibited monomorphic pattern by showing only $\mathrm{KK}$ genotype pattern (Figure 1) in current experimental Gaolao cattle population. Similar with the findings in current study, indigenous cattle exhibited fixation of $\mathrm{K}$ allele was found in Ongole cattle (Krovvidi et al., 2013) and Haryana Cattle. The predominance of average $\mathrm{K}$ allele frequency (0.915) in Gir and Kankrej indigenous zebu cattle as compared to A allele frequency (0.085) was found while genotyping at CfrIRFLP locus (Patel et al., 2017). Ganguly et al., (2013) reported the frequency of A allele in Frieswal and Sahiwal cattle was 0.36 and 0.04 , respectively.

However, in Tarurine cattle exhibited lower frequency of $\mathrm{K}$ allele \& higher frequency of A allele. Krovvidi et al., (2013) reported frequencies of $\mathrm{K}$ and $\mathrm{A}$ alleles as 0.74 and 0.26 in Jersey crossbred and 0.60 and 0.40 in Friesian crossbred cows for DGAT1/CfrI polymorphism. PCR-RFLP using $C f r \mathrm{I}$ restriction enzyme in 100 Iranian Holstein Cattle revealed KK, KA and AA genotype frequencies as $0.31, \quad 0.41$ and 0.28 , respectively. The allele frequencies of $\mathrm{K}$ and A alleles were estimated as 0.515 and 0.485 , respectively (Ahani et al., 2015). In Polish Holstein-Friesian bulls the frequencies of $\mathrm{K}$ and $\mathrm{A}$ alleles were 0.54 and 0.46 , respectively at DGAT1-CfrI locus (Woszuk et al., 2008).

\section{PCR-RFLP DGAT1G2-BglI locus}

Restriction digestion analysis of 378 bp PCR product of the Exon-VIII region of DGAT1 gene with $B g l$ I enzyme reveled two genotype patterns in studied Gaolao cattle population. The first pattern with two fragments of 282 and 96 bp was designated as AA (K) genotype and second pattern with three fragments was obtained $(254,96 \& 28 \mathrm{bp})$ was referred as GC (A) heterozygous genotype (Figure 2).

DGAT1G2-BglI locus was found polymorphic with genotype frequency for homozygous AA $(\mathrm{K})$ genotype as 0.975 and for GC(A) genotype the frequency was found as 0.025 . The allele frequency for the $\mathrm{K}$ alleles was found 0.9875 and for allele $\mathrm{A}$ was 0.0125 at DGAT1G2- BglI locus. (Table 3). The non significant $(\mathrm{P}>0.05)$ Chi-square value for all the genotypes showed HardyWeinberg law in equilibrium. Higher $\mathrm{K}$ allele frequency was reported by various other researchers. Komisarek et al., (2011) studied the effects of polymorphisms in DGAT1 genes using $B g l$ I restriction enzyme to find out its relation with reproduction and production traits in 209 Jersey cows \& reported that allelic frequencies for $\mathrm{K}$ and $\mathrm{A}$ alleles as 0.79 and 0.21 respectively at DGAT1-BglI locus. The average and standard error of Fat \%, Protein \%, SNF\% \& Lactose\% exhibited non-significant effect of all genotypes. The Karl Pearson correlation analysis indicated the relationship between genotypes with milk components was nonsignificant $(\mathrm{P}>0.05)$. 
Table.1 Name, region, primer nucleotide sequence and restriction enzymes used to screen polymorphism in DGAT1 gene of Gaolao cattle

\begin{tabular}{|c|l|l|l|l|}
\hline $\begin{array}{c}\text { Sr. } \\
\text { No. }\end{array}$ & $\begin{array}{c}\text { Name of } \\
\text { Primer \& } \\
\text { Region }\end{array}$ & \multicolumn{1}{|c|}{ Primer Sequence } & $\begin{array}{c}\text { Produc } \\
\text { t Size } \\
\text { (bp) }\end{array}$ & \multicolumn{1}{|c|}{ Reference/RE } \\
\hline 1. & $\begin{array}{l}\text { DGAT1G1 } \\
\text { Exon VIII }\end{array}$ & $\begin{array}{l}\text { FP 5'-GCACCATCCTCTTCCTCAAG-3' } \\
\text { RP5'-GGAAGCGCTTTCGGATG-3' }\end{array}$ & 411 bp & $\begin{array}{l}\text { (Winter et al., } \\
\text { 2002) / CfrI }\end{array}$ \\
\hline 2. & $\begin{array}{l}\text { DGAT1G2 } \\
\text { Exon VIII }\end{array}$ & $\begin{array}{l}\text { FP5'-TGCCGCTTGCTCGTAGCTTTGGCC-3' } \\
\text { RP5'-ACCTGGAGCTGGGTGAGGAACAGC-3' }\end{array}$ & 378 bp & $\begin{array}{l}\text { (Komisarek et } \\
\text { al., 2011) / BglI }\end{array}$ \\
\hline 3. & $\begin{array}{l}\text { DGAT1G3 } \\
\text { Intron I }\end{array}$ & $\begin{array}{l}\text { FP 5' -TGGCTTCTGCAGTGGACTC-3' } \\
\text { RP 5'-ACAGGAGCTGGTGATGCAA-3' }\end{array}$ & 212 bp & Designed \\
\hline 4. & $\begin{array}{l}\text { DGAT1G4 } \\
\text { Exon VIII }\end{array}$ & $\begin{array}{l}\text { FP5'-CGTAGCTTTGGCAGGTAAGG-3' } \\
\text { RP 5'-AGTTGAGCTCGTAGCACAGG -3' }\end{array}$ & 198 bp & Designed \\
\hline
\end{tabular}

Table.2 Restriction digestion reaction of DGAT1G1 and DGAT1G2 PCR amplified Products of DGAT1 gene in Gaolao Cattle

\begin{tabular}{|c|l|c|c|c|c|c|c|}
\hline $\begin{array}{c}\text { Sr. } \\
\text { No. }\end{array}$ & \multicolumn{1}{|c|}{ RE } & \multicolumn{3}{|c|}{ DGAT1G1-CfrI } & \multicolumn{3}{c|}{ DGAT1G2- BglI } \\
\hline & $\begin{array}{c}\text { Components } \\
\text { 1. }\end{array}$ & $\begin{array}{l}\text { Initial } \\
\text { Concentration }\end{array}$ & Volume & $\begin{array}{c}\text { Final } \\
\text { concentration }\end{array}$ & $\begin{array}{c}\text { Initial } \\
\text { Concentration }\end{array}$ & Volume & $\begin{array}{c}\text { Final } \\
\text { concentration }\end{array}$ \\
\hline Buffer & $10 \mathrm{X}$ & $2.5 \mu \mathrm{l}$ & $1 \mathrm{X}$ & $10 \mathrm{X}$ & $2.5 \mu \mathrm{l}$ & $1 \mathrm{X}$ \\
\hline $\mathbf{2}$ & $\begin{array}{l}\text { Amplified } \\
\text { PCR product }\end{array}$ & - & $10 \mu \mathrm{l}$ & $500 \mathrm{ng}$ & - & $10 \mu \mathrm{l}$ & $500 \mathrm{ng}$ \\
\hline $\mathbf{3}$ & $\begin{array}{l}\text { Restriction } \\
\text { Enzymes }\end{array}$ & $5 \mathrm{U} / \mu \mathrm{l}$ & $0.4 \mu \mathrm{l}$ & $2 \mathrm{U}$ & $10 \mathrm{U} / \mu \mathrm{l}$ & $0.5 \mu \mathrm{l}$ & $5 \mathrm{U}$ \\
\hline $\mathbf{4}$ & MBG water & - & $\mathrm{Upto}$ & - & - & $\begin{array}{c}\text { Upto } \\
25 \mu 1\end{array}$ & - \\
\hline
\end{tabular}

Table.3 Allele and genotype frequency at DGAT1G2- BglI locus in Gaolao cattle

\begin{tabular}{|l|c|l|c|c|c|c|}
\hline Name of Locus & $\begin{array}{l}\text { Sample } \\
\text { No. (N) }\end{array}$ & \multicolumn{4}{|l|}{$\begin{array}{l}\text { Allele } \\
\text { frequencies }\end{array}$} & \multicolumn{3}{|l|}{ Genotype frequencies } \\
\cline { 3 - 7 } & & K & A & KK & KA & AA \\
\hline DGAT1G2- BglI & $40^{\text {NS }}$ & 0.9875 & 0.0125 & 0.975 & 0.025 & 0.000 \\
\hline
\end{tabular}

NS- Non Significant at $\mathrm{P}>0.05$ 

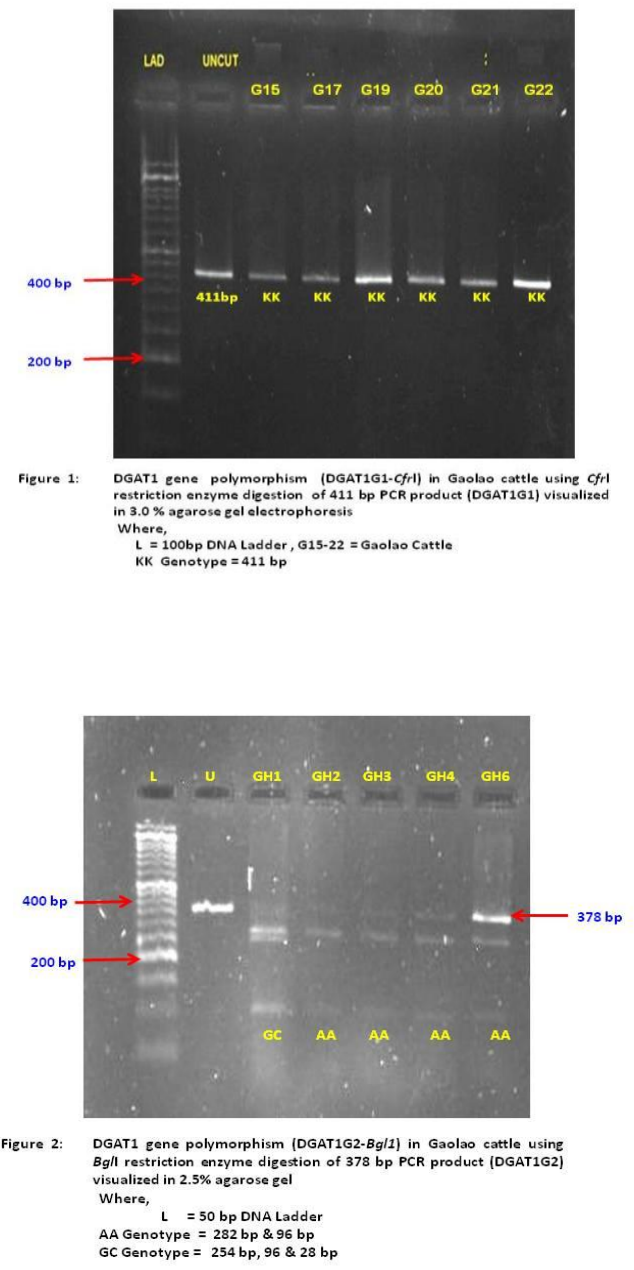

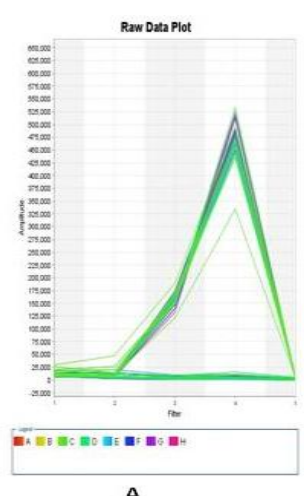

A

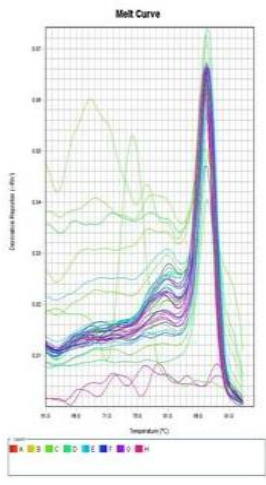

B

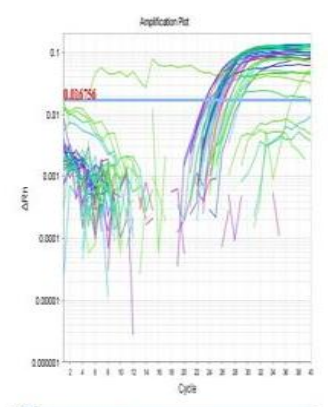

WA

c

Figure 3: HRM Analysis (A) Raw data plot of HRM of DGAT1G3, (B) Melting Curve of HRM using DGAT1G3 amplicons \& (C) Amplification plot 


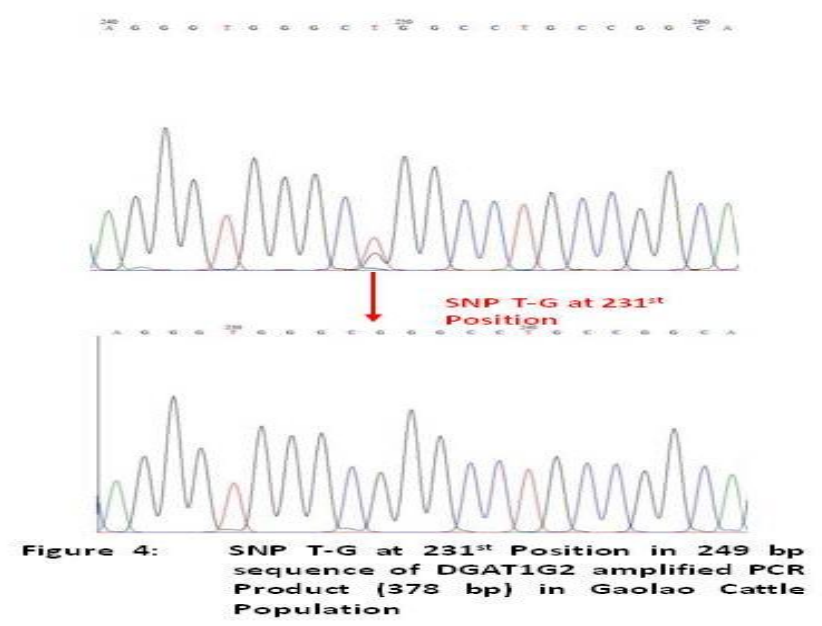

\section{HRM analysis}

The amplicons of 212 bp DGAT1 gene fragments of intron 1 were processed for HRM analyses in which the aligned plot didn't exhibit differences in their melt curve behaviour indicating the absence of variation (Figure 3). However, random samples were selected for sequencing to know variation sites in the region of gene in Gaolao Cattle.

\section{DNA Sequence Analysis of polymorphic patterns at DGAT1G2- BglI Locus}

The PCR products (378 bp) of the Exon-VIII region of DGAT1 gene exhibited polymorphism in PCR-RFLP analysis using $B g l \mathrm{I}$ enzyme which revealed $\mathrm{KK}$ \& $\mathrm{KA}$ genotypes approximately of $378 \mathrm{bp}$ for KK \& $282 \mathrm{bp}, 254 \mathrm{bp}$ and $96 \mathrm{bp}$ for KA genotypes respectively. In view of detecting exact nucleotide change for the polymorphic restriction site, we selected 02 PCR products representing $\mathrm{KK} \& \mathrm{KA}$ genotypes for forward and reverse sequencing (04 reactions) with purification. These obtained sequences were first edited for getting consensus sequence for genotype $\mathrm{KK} \& \mathrm{KA}$ by removing misamplified sequences after validating them with their chromatographic peaks using
BioEdit software. The forward sequence and reverse primer sequence was aligned using $\mathrm{T}$ Coffee, multiple sequence alignment programme to find out the regions of similarity as the sequence of the KK Genotype (GB-38) and for KA genotype (GH-1) DGAT1G2-BglI locus in Gaolao Cattle. The Final edited sequences for both the genotypes were aligned using ClustalW Omega tool which reveled one Transversion SNP T-G at $231^{\text {st }}$ position in DGAT1G2 amplified PCR product query sequence of DGAT1 gene in Gaolao Cattle. The same SNP was validated using sequence chromatograms of two different genotypes (Figure 4). The sequence alignment of $249 \mathrm{bp}$ DGAT1G2 amplified DNA sequence of DGAT1 gene of Gaolao cattle with Bos taurus reference sequence (AJ318490) revealed total of 02 SNPs viz; T-C at $217^{\text {th }}$ position \& G-T at $232^{\text {nd }}$ position. In order to know the sequence homology of DGAT1G2 amplified $249 \mathrm{bp}$ sequence of DGAT1 gene of Gaolao cattle with other species BLAST analysis was performed \& developed BLAST tree view revealed sequence identity of 99.20 with European cattle, Yak and 98.80 with Buffalo, 97.99 with Sheep,97.59 with Goat respectively. 
DNA Sequence analysis of DGAT1G3 Amplified 212 bp DGAT1 Amplicon in Gaolao Cattle

The obtained edited DGAT1G3 amplified sequence of $219 \mathrm{bp}$ size of Gaolao cattle was aligned with reference sequence (Accession No. AJ318490) using CLUSTAL alignment tool which revealed 03 polymorphic sites as computational SNPs i.e. SNP G $-\mathrm{A}$ at $51^{\text {st }}$ position, at $52^{\text {nd }}$ position as SNP G-A, and at $67^{\text {th }}$ position as SNP A-G. In order to know the sequence homology of Gaolao DGAT1G3 amplified region of DGAT1 gene with other species BLAST analysis was performed \& developed BLAST tree view which revealed sequence identity of $97.66 \%, 97.18 \%, 96.71 \%$, $88.29 \%, 87.22 \%$ and $86.44 \%$ with Bos indicus, Bos taurus, Bos mutus, Bubalus bubalis, Capra hircus \& Ovies aries respectively. The query sequence was closely related with Bos indicus and Bos taurus DGAT1 sequences as compared to Bubalus bubalis, Capra hircus and Ovies aries sequences.

\section{DNA Sequence analysis of DGAT1G4 amplified 198 bp DGAT1 Amplicon in Gaolao Cattle}

The obtained edited DGAT1G4 amplified sequence of $140 \mathrm{bp}$ size of Gaolao cattle was aligned with reference sequence (Accession No. AJ318490) using CLUSTAL alignment tool which revealed 01 polymorphic sites as computational SNPs at $23^{\text {rd }}$ position as SNP C-A. In order to know the sequence homology of Gaolao region gene with other species BLAST analysis was performed \& developed BLAST tree view which revealed sequence identity of $99.28 \%$ with Zebu, European cattle, Buffalo, Yak and $98.56 \%$ with Goat, $97.84 \%$ with Camel and Sheep and Pig $90 \%$ respectively.

In conclusion, it is to state that restriction digestion analysis at DGAT1-CfrI locus exhibited monomorphic pattern and DGAT1G2-BglI locus was found polymorphic pattern in experimental Gaolao cattle. DGAT1G2-BglI locus was found polymorphic with allele frequency for the $\mathrm{K}$ alleles as 0.9875 and for allele $\mathrm{A}$ as 0.0125 . The result of analysis variance showed nonsignificant $(\mathrm{P}>0.05)$ effect of all genotypes on milk components which may be due to small sample size resulting in higher error variance. The DGAT1G2 amplified PCR products revealed one SNP T-G at $231^{\text {st }}$ position in of AA (K) \& GC (A) genotypes in Gaolao Cattle. The DGAT1G3 amplified sequence revealed 03 polymorphic sites as computational SNPs at $52^{\text {nd }}$ position as SNP G-A, at $51^{\text {st }}$ position as SNP G $-A$ and at $67^{\text {th }}$ position as SNP A-G. DGAT1G4 amplified sequence revealed 01 polymorphic sites as computational SNPs at $23^{\text {rd }}$ position as SNP C-A. In present study, it was found that the allele $\mathrm{K}$ at DGAT1-CfrI locus was fixed in experimental Gaolao Cattle population. The polymorphisms at regions DGAT1 gene in Gaolao Cattle were revealed which after validation may aid in development of candidate gene markers for selection and genetic improvement of indigenous cattle.

\section{Acknowledgement}

The authors duly acknowledges the financial support by the funding agency SERB-DST, GOI under Scheme Core Research Grant (File No.EMR/2017/000323), PI- Dr.D.S.Kale, Assistant Professor at Deptt. of AGB, NVC, MAFSU, Nagpur. The help rendered by Members of Gaolao Breeder's Association in survey and phenotyping of Gaolao cattle in the breeding tract is duely acknowledged.

\section{References}

Ahani, S., Mashhadi, M.H., Nassiri, M., Aminafshar, M. and Haddadi, M. 2015. 
Characterization of single nucleotide polymorphism in diacylglycerol acyltransferase (DGAT1) gene loci of Iranian Holstein Cattle. Research Opinions in Animal and Veterinary Sciences. 5 (5):231-236.

Bennewitz,J.,Paul,N.S.,Reinsch,C.,Looft, B., Kaupe,C., Weimann,G., Erhardt,G., Thaller, C., Kühn, M., Schwerin, H., Thomsen, H., Reinhardt, R.,Reents, B. and Kalm, E. 2004. The DGAT1 $\mathrm{K} 232 \mathrm{~A}$ mutation is not solely responsible for the milk production quantitative trait locus on the bovine chromosome 14. Journal of Dairy Science. 87:431-442.

Berry, D.P., Howard,D., O'Boyle,P., Waters,S., Kearney, J. F. and McCabe, M.2010. Associations between the K232A polymorphism in the diacylglycerol-O-transferase 1 (DGAT1) gene and performance in Irish Holstein-Friesian dairy cattle. Irish Journal of Agricultural and Food Research. 49: 1-9.

Bruford, M. W., Bradley, D. G. and Luikart, G. 2003. DNA markers reveal the complexity of livestock domestication. Nature Reviews Genetics. 4 (11):90010.

Devlin, B.,Risch, N. (1995). A Comparison of Linkage Disequilibrium Measures for Fine-Scale Mapping. Genomics. 29: 311-322.

Fangyu L., Cuicui C., Kaixing, Q., Jianyong, L., Yutang, J., Quratulain, H.,Ningbo, C., Jicai, Z.,Hong, C.,Bizhi, H.,Chuzhao, L. 2020. DGAT1 K232A polymorphism is associated with milk production traits in Chinese cattle. Animal Biotechnology, 1-5.

Frison E.A., Cherfas, J. and Hodgkin, T. 2010. Agricultural Biodiversity Is Essential for a Sustainable Improvement in Food and Nutrition Security. Sustainability, 3:238-253.
Ganguly, I., Kumar,S., Gaur,G. K., Singh, U., Kumar, A., Kumar, S. and Mann, S. 2013. DGAT1 polymorphism K232A in Sahiwal (Indian zebu) and Frieswal (Holstein Friesian x Sahiwal crossbred) cattle. Indian Journal of Animal Research. 47 (4): 360-363.

Grisart, B., Coppieters,W.,Farnir,F., Karim, L., Ford, C., Cambisano, N.,Mni,M., Reid,S., Spelman,R., Georges,M. and Snell, R.2002. Extensive genome-wide linkage disequilibrium in cattle. Genome Research. 12: 222-231.

Heaton, M., Harhay, G.P., Bennett,G.L., Stone, R.T., Grosse,W.M., Casas, E., Keele, J.W., Smith,T.P., ChitkoMcKown, C.G. and Laegreid, W.W. 2002. Selection and use of SNP markers for animal identification and paternity analysis in U.S. beef cattle. Mammalian Genome. 13 (5):272-81.

Kargirwar, S.V. (2004). Breed characterization of Gaolao cattle in Wardha district of Vidarbha region. M.V.Sc thesis submitted to Maharashtra Animal and Fishery Sciences University, Nagpur. pp 40.

Kaupe, B., Winter,A., Fries,R., Erhard, G. 2004. DGAT1 polymorphism in Bos indicus and Bos taurus Cattle breeds. Journal of Dairy Research. 71: 182187.

Kennedy, E. 1957. Metabolism of lipids. Annual Review of Biochemistry, 26: 119-148.

Komisarek, J., Michalak,A. and Walendowska, A. 2011. The effects of polymorphisms in DGAT1, GH and GHR genes on reproduction and production traits in Jersey cows. Animal Science Papers and Reports. 29:29-36.

Krovvidi, S. (2013). Genetic Polymorphism of STAT5A, DGATI and CYP19 Genes and Their Association with Milk Production Traits in Cattle and 
Buffaloes. M.V.Sc. thesis submitted to Tamil Nadu Veterinary and Animal Sciences University.

Lacorte, G.A., M.A. Machado, M.L. Martinez, A.L. Campos, R.P. Maciel, R.S. Verneque, R.L., Teodoro, M.G., Peixoto, M.R., Carvalho and Fonseca, C.G. 2006. DGAT1 K232A polymorphism in Brazilian cattle breeds. The Genetics and Molecular Research. 5 (3):475-82.

Nielsen, D.M., Ehm,M.G. and Weir, B.S.1998. Detecting Marker-Disease Association by Testing for HardyWeinberg Disequilibrium at a Marker Locus. A Journal of Human Genetics. 63(5):1531-40.

Patel, J. and Chauhan, J. 2017. Evaluation of DGAT1-exon $8 \mathrm{~K} 232 \mathrm{~A}$ substitution in Gir and Kankrej (BosIndicus), Indian origin Cattle and its association with milk production traits. Genetika. 49 (2) :627 - 634.

Patel, R.K., Chauhan, J.B., Soni,K. J. and Singh, K.M. 2009. Genotype and allele frequencies of DGAT1 gene in Indian Holstein bulls. Current Trends in Biotechnology and Pharmacy. 3: 386389.

Weiss, S. B., and Kennedy, E.P. 1956. The enzymatic synthesis of triglycerides. Journal of American Chemical Society.
78 (14): 3550-3550.

Winter, A., W. Kramer, F.A. Werner, S. Kollers, S. Kata, G. Durstewitz, J. Buitkamp, J.E.Womack, G. and Fries, R. 2002. Association of a lysine232/alanine polymorphism Thaller in a bovine gene encoding acyl-CoA: triacylglycerol acyltransferase (DGAT1) with variation at a quantitative trait locus for milk fat content. Proceedings of the National Academy of Sciences of the United States of America. 99:9300-9305.

Wittwer, C.T., Reed,G.H., Gundry,C.N., Vandersteen,J.G. and Pryor,R.J. 2003. High resolution genotyping by amplicon melting analysis using LC Green. Clinical Chemistry. 49: 853860.

Woszuk, N. J., A. Noskowiak,T. St. rabel, T. Jankowski and M.Świtoński .2008. An effect of the DGAT1 gene polymorphism on breeding value of Polish Holstein-Friesian sires. Animal Science Papers and Reports. 26: 17-23.

Yeh, F.C. and Boyle,T.J.B. 1997. Population Genetic Analysis of Codominant and Dominant Markers and Quantitative traits. Belgian Journal of Botany. 129:157-163.

\section{How to cite this article:}

Pantawane, S. N., D. S. Kale, P. G. Koringa and Patil, D. V. 2021. SNPs within Exon VIII of DGAT1 Gene in Gaolao Cattle. Int.J.Curr.Microbiol.App.Sci. 10(01): 1530-1539.

doi: https://doi.org/10.20546/ijcmas.2021.1001.179 